\title{
Substrate specificity among Diptera in decaying bioenergy wood: can they be conserved by the same measures as are currently applied to beetles?
}

\author{
Mats Jonsell ${ }^{1}$ (D) $\cdot$ Lina A. Widenfalk $k^{1,2} \cdot$ Sven Hellqvist $^{3}$ (D)
}

Received: 29 November 2019/Revised: 21 April 2020/Accepted: 12 May 2020/

Published online: 22 May 2020

(C) The Author(s) 2020

\begin{abstract}
Although threatened by forestry, our knowledge concerning saproxylic insects is strongly biased towards well-known orders, mainly beetles (Coleoptera). The beetles have, therefore, formed the basis on which conservation measures of other groups have been formulated. Despite being more species-rich, the Diptera have been rather neglected. Moreover, our limited knowledge of the Diptera suggests that their demands on the dead wood substrate differ markedly from that of coleopterans. We tested if this is true by comparing the substrate requirements of dipteran and coleopteran species by analysing the affinities of species assemblages for logging residues differing in age, size, and tree species. Insects were reared out from the same samples of bioenergy wood from clear-cuts in Sweden. 15 species of Brachyceran flies were compared with 56 species of Coleoptera. We found the average level of specialisation to be similar between the two groups, but the dipterans had (contrary to the expectations) a higher proportion of specialists. Affinities for differently aged wood were similar. More dipterans than beetles were associated with the coarsest wood (diameter $9 \mathrm{~cm}-15 \mathrm{~cm}$ ). More dipterans than beetles tended to be associated with aspen (Populus tremula), while Coleoptera tended to be more associated than Diptera with oak (Quercus) and spruce (Picea abies). We conclude that most recommendations for conserving the saproxylic beetle fauna also seem to benefit dipterans, but that the dipterans might be even more sensitive to which qualities of the wood that is preserved. The high conservation value of aspen is already recognised and our results for dipterans strengthen this. The high incidence of many dipteran species in logging residues suggests that many dipterans use sun-exposed environments.
\end{abstract}

Keywords Beetles · Coleoptera · Diptera · Flies · Niche breadth · Saproxylic · Specialisation

Communicated by Jens Wolfgang Dauber.

Extended author information available on the last page of the article 


\section{Introduction}

Among the saproxylic organisms, i.e. organisms dependant on dead wood, many species are recognised as being threatened by forestry. In managed forests, most of the wood is harvested, leaving only small amounts to decay naturally, thus providing much less habitat for saproxylic species compared to natural forests (Stokland et al. 2012). The amount of dead wood has decreased further during the last two decades when logging residues have also been harvested to provide bioenergy (Lundborg 1998). To mitigate the problems for saproxylic biodiversity, forestry has modified its operations, e.g. by leaving high stumps, groups of trees, or certain selected stands. The recommendations on how such modifications should be performed in order to maximize benefits to organisms are based on our current knowledge of these ecosystems. This naturally focuses on well-known speciesgroups, which, for saproxylic insects, almost exclusively means beetles (Coleoptera). However, in dead wood the Diptera (midges and flies) is probably even more species-rich than the Coleoptera (Stokland et al. 2012), although we have only vague knowledge about most dipteran species' requirements (Rotheray et al. 2001). If these requirements differ from those of beetles, we may need to modify these recommendations in order to implement measures that will also benefit the Diptera.

A species' risk of extinction is thought to be associated with its level of specialisation, especially during periods of large changes in land use or climate. Generalists are more likely to be able to adapt to new conditions (Clavel et al. 2011). The level of specialisation can be defined as the niche breadth of the species, i.e. the ecological and habitat range over which a species can perform its functional role in a community (Chesson 2000; Hutchinson 1959). Saproxylic organisms specialise on certain qualities of dead wood; the range of types of dead wood they use is likely an important feature determining how they may be able to adapt to new conditions. Extinction risk is, moreover, associated with the specific niche a species occupies. If associated with a niche or substrate that is rare or decreasing, the risk of extinction is higher (IUCN 2001).

It has been estimated that there are 2000 saproxylic species of Diptera in Scandinavia, which is considerably more than the estimated 1450 species of saproxylic Coleoptera (Stokland et al. 2012). The estimate for Diptera is, compared to beetles, rather coarse because our knowledge of larval substrates is vague (Rotheray et al. 2001). In some cases, it is not even known if wood or something else is the larval substrate because dipterans have usually been collected as adults by netting or in traps. The exceptions are dipterans that live in fruiting bodies of saproxylic fungi (Jakovlev 1994, 2011) and a few other species (e.g. Rotheray et al. 2001). Beetles on the faunal list have usually been hand-picked or reared out from pieces of wood, giving precise details of the substrates used during their larval development (Köhler 2000; Palm 1959; Saalas 1917). Dipteran larvae are also to be found in dead wood, but have been severely under-recorded in biological surveys (Rotheray 2016).

There is scant evidence in the literature concerning differences between Diptera and Coleoptera in the quality of wood they select. Many saproxylic beetles are associated with warm, sun-exposed wood substrates (Jonsell et al. 1998; Kouki et al. 2001; Lindhe and Lindelöw 2004), whereas dipterans are usually associated with moister environments (Rotheray et al. 2001; Økland et al. 2005). For both groups the microhabitat is important (Jonsell et al. 1998; Rotheray et al. 2001). Dipterans seem less restricted to certain tree species (Rotheray et al. 2001), which suggests that they might be less specific to certain attributes of the wood substrates. However, contradictory evidence comes from a study on 
nematocerans which found large differences in species assemblages on a local scale in different pieces of aspen-wood (Halme et al. 2013). Irmler et al. (1996) found as much as $70 \%$ of the Mycetophilidae-species only in beech-wood (not in spruce or alder) but the study design makes precise conclusions for tree-species associations doubtful.

In the present study, therefore, our objective has been to compare species of Diptera with species of Coleoptera in the specificity with which they utilize substrates, i.e. their realized niche (Verberk et al. 2010). Our survey materials were insects collected in a systematic sampling of bioenergy-wood. The questions we aimed to answer were:

- What associations exist between substrates and species of Diptera encountered in the study?

- By estimating niche-breadths, can we show dipterans to be less specific than coleopterans in their substrate choice?

- Are there differences between Diptera and Coleoptera in the categories of wood with which they are associated?

\section{Material and methods}

Samples of logging residue wood were collected from 40 clear-cuts in southern Sweden from autumn 2003 to Spring 2004. Three main factors were to be compared: tree species (four species), diameter (three classes), and substrate age (two ages). To ensure that we collected all factor-combinations evenly within the sampled area, it was divided into 14 regions with the same sampling in each region. Suitable clear-cuts in each region were identified by foresters at the Forestry board, Holmen, Sveaskog, Korsnäs and Stora according to our specified criteria: age since cutting and tree-species composition.

From each clear-cut we sampled four tree species: aspen (Populus tremulae L.), birch (Betula pubescens Ehrh. and B. verrucosa Ehrh.), oak (Quercus robur L.), and spruce (Picea abies (L.) Karst.). However, it was impossible to find all four tree-species in some of the clear-cuts. If we were able to find the missing tree species at a nearby clear-cut, the samples were taken there instead. For each tree species, we took samples from three diameter classes: Thin $(1-4 \mathrm{~cm})$, Medium $(4-8 \mathrm{~cm})$ and Coarse $(8-15 \mathrm{~cm})$. The two thinner classes are usually defined as fine woody debris, whereas the coarsest class is generally defined as coarse woody debris. From each clear-cut, we sampled two bundles of each combination of tree species and diameter class, giving 24 bundles of wood per clearcut. The substrate age could be compared as the clear-cuts were chosen in pairs of two ages situated between $1 \mathrm{~km}$ and $3 \mathrm{~km}$ from each other, where one clear-cut was one summer (Young) and the other between 3 and 5 years old $($ Old $)$, thus giving 20 clear-cuts of each age.

The sampled wood was cut into $50 \mathrm{~cm}$ lengths and packed together in $25 \mathrm{~cm}-35 \mathrm{~cm}$ diameter bundles. The bundles were brought to the laboratory, where the insects were reared out of the wood in a greenhouse at a temperature of about $20{ }^{\circ} \mathrm{C}$. There were some deviations from this temperature, especially during warm days in the summer, but all samples within the same rearing cohort experienced the same temperature regime. The rearing continued for at least three months. More details on the sampling procedure can be found in Jonsell et al. (2007). That source include also data on the quantity of wood in the samples.

For practical reasons we had to use two types of rearing container: textile sacs and wooden boxes. To account for the effects of using different rearing containers (Jonsell and 
Hansson 2007), one of each bundle type (site, tree species and diameter combination) was enclosed in each type of container. For rearing in textile sacs, the bundles of wood were hung from the ceiling by a string, then enclosed in a cotton sac with metal wires on the inside to prevent the wood coming into direct contact with the sac. The insects were collected in a plastic vial attached to a plastic funnel at the bottom of the cotton sac. The remaining wood bundles were placed in boxes made of plywood. Insects were collected in a glass vial inserted in one gable end. At the end of the rearing period, the remains from the bottom of the wooden box were also inspected for insects, since not all insects were caught in the vials.

To compare the surface areas and volumes of the bundle categories, the number of wood pieces in every bundle was counted and multiplied by the area/volume of a piece representing the median for the class (Jonsell et al. 2007). All bundles had similar bark surface areas (Jonsell et al. 2007). Consequently, the volume of firm wood was largest for the coarsest diameter class. For most saproxylic species, especially in the early stages of wood decay, the surface area is probably a better descriptor of the amount of habitat than wood volume, because such species live in the space between the bark and the wood.

Dipterans of some selected groups (Tipulidae and true flies except Phoridae and "Calyptrata") were determined to species or the lowest possible level by Sven Hellqvist, Marc Pollet (Medetera) and Iain MacGowan (Lonchaea). Some dipteran data were only analysed at genus-level if our knowledge of their biology indicated that all species recorded in the present study had similar requirements. The saproxylic beetles were determined to species in an earlier study (Jonsell 2008).

\section{Statistics}

In total 612 samples were used in the analyses, excluding 348 samples that could not be collected (due to lack of some tree species in some locations) or missing data. Data inspection ensured that all factorial combinations were evenly included and distributed throughout the area, suggesting no risk of bias in the sampling design. Initial preliminary analyses showed that region and rearing method had none or very minor effect, when they were included as co-variables. Since our main question of the study was wood type affinity, these variables were therefore excluded from further analyses.

Associations with categories of wood types were modelled with generalized linear models (GLM) where the response variable, abundance of a species, was explained by the three categorical wood type variables. GLM was preferred over a simpler index of niche breadth (e.g. the proportional similarity (PS) index (Feinsinger et al. 1981)) since we expected the combination of our three variables (tree species, diameter and substrate age) to potentially be relevant for the associations. Analyses were done for all species with $>10$ occurrences (in unique samples). We used the function glm in $\mathrm{R}$ version 3.5.1 (R Core Team 2018) to fit the models, assuming a Poisson distribution. Using the same distribution for all species was preferred over adjusting to potential deviations from the Poisson distribution for some species as this ensures the comparability of the model coefficients in further analysis (Gelman and Hill 2007). It is not likely to cause any one-directional bias since we are not using significance test for the individual models (Olsson 2002). The models were used to define the niches of each species as described below.

Niche breadth was assessed for each species by the share of wood categories that belonged to the niche, with a value between $1 / \mathrm{n}$ (one of $\mathrm{n}$ categories in the niche) and 1 (all categories used, hereafter called All used). It was first calculated for each variable 
individually, and those values were subsequently multiplied into a total niche breadth (described below). Initially, we tested which variable/-s that could explain a relevant amount of the variation in a forward selection process. We used AIC-informed forwardstep selection of the three variables ('step' function within the $\mathrm{R}$ statistical package). Variables were included if $\mathrm{k}>2$, i.e. if inclusion of the variable lowered AIC by 2 or more (Venables and Ripley 2002; Burnham and Anderson 2002). Variables not explaining a relevant amount of variation in abundance (i.e. not included by the forward-step selection) were assigned a niche breadth $=1$.

For variables that could explain a relevant amount of variation we assessed which categories that belonged to the niche by comparing the abundance in each wood category relative to the category with highest abundance. For this we used coefficients obtained from species-specific full models (i.e. with all three variables included). Coefficients were calculated by predicting the response variable (i.e. abundance) for all variable combinations (including those variables that did not explain any variation), and for each focal variable we summarized the mean abundance under all other combinations (Gelman and Hill 2007). Categories within a variable that had the highest abundance or a relative abundance $\geq 0.5$ of the highest abundance, were defined as a primary niche. Categories with a relative abundance of $0.5-0.1$ compared to the highest abundance were defined as a secondary niche. If the relative abundance was lower than 0.1 , the category was defined as a non-niche. The niche breadth within a variable was then calculated by dividing the number of used niches with the number of categories, where secondary niches were downweighted to a half niche. Thus, an association with one of the four tree species gave a niche breadth of 0.25 for that variable. An additional secondary association to another tree species added in that case 0.125 , so the niche breadth then summarized to 0.375 . The total niche breadth for a species was the multiplication of the three variables' niche breadths.

Mean niche breadth was compared between dipterans and coleopterans with t-tests. Whether the two groups had different proportions of specialists/generalists was tested with a Chi square test. For this, species were categorised as specialists, intermediate or generalists, with the respective cut off values of niche breadth $\leq 0.25 ;>0.25$ to $\leq 0.40$ and $>0.40$. The $\leq 0.25$-limit for specialists were chosen to represent a species using only one tree species, regardless of diameter and substrate age. The $>0.4$-limit represent a species that is found in all tree species but have some differences in affinity to diameter and age.

We compared the variable-categories with which Diptera and Coleoptera are mainly associated by counting the number of associated species. When a species was associated with no variable it was counted in an additional category as All used. For Age and Diameter we counted only the categories to which each species had its strongest association, as those variables are ordinal. For Diameter, associations were defined only with the two extreme categories (Thin or Coarse) even though in some cases Medium had the highest value. However, Medium was never the only category that any species used and it is biologically unlikely that a species would have such a narrow diameter association that Medium would in reality be higher than both the two extremes (Siitonen and Stokland 2012; Ehnström and Axelsson 2002; Jonsell et al. 2007). Therefore, species estimated to have Medium as their single primary niche and both Coarse and Thin as secondary niches were assigned as All used (refining the analyses based on our ecological knowledge as suggested by Gelman and Hill 2007). Similarly, when Medium was single primary niche and either Coarse or Thin was the secondary niche, species were assigned to that respective secondary niche. The variable Tree species is not ordinal, and therefore all tree species with which an insect species had an association (both primary and secondary) were counted. We tested if there 
was a statistically significant difference $(\mathrm{p}<0.05)$ between the two organism groups in the proportion of species associated with different categories of Age and Diameter with a Chisquare test for contingency tables. For Tree species, the same test was done for each tree species individually, because one insect species may be associated with more than one tree species. Statview 5.0.1 for Mac was used for the Chi-square tests.

\section{Results}

In total, 66 Diptera taxa were identified, most of them to species level. A large amount of Nematocera (midges and gnats) and a smaller quantity of Brachycera (true flies) (e.g. the species-rich families Phoridae, Anthomyiidae and Muscidae) were not included.

Table 1 Dipteran species from logging residues, including the species numerous enough to undergo statistical analysis. Their habitat associations as shown by modelling ("Appendices 1, 2") are indicated by the categories within each variable that had an association. Within parentheses are secondary categories of substrate, categories which the species use-but less frequently

\begin{tabular}{|c|c|c|c|c|c|c|}
\hline \multirow[t]{2}{*}{ Species } & \multicolumn{2}{|c|}{ No of } & \multicolumn{3}{|c|}{ Substrate associations } & \multirow{2}{*}{$\begin{array}{l}\text { Niche } \\
\text { breadth }\end{array}$} \\
\hline & Obs & Inds & Age & Diameter & Tree species & \\
\hline Drapetis abrollensis & 18 & 58 & Old & Medium (Coarse) & $\begin{array}{l}\text { Birch (Aspen, } \\
\text { Oak) }\end{array}$ & 0.13 \\
\hline Gaurax spp. ${ }^{\mathrm{a}}$ & 11 & 29 & $\begin{array}{l}\text { Old } \\
\text { (Young) }\end{array}$ & Coarse (Medium) & Aspen (Birch) & 0.14 \\
\hline Lonchaea fugax & 12 & 332 & Young & Coarse & Aspen & 0.04 \\
\hline Lonchaea fraxina & 17 & 68 & Old & $\begin{array}{l}\text { Thin, Medium } \\
\text { (Coarse) }\end{array}$ & Aspen & 0.10 \\
\hline Lonchaea patens & 20 & 43 & Old & All used & Aspen & 0.13 \\
\hline Lonchaea sylvatica & 12 & 23 & All used & $\begin{array}{l}\text { Coarse, Medium } \\
\text { (Thin) }\end{array}$ & All used & 0.83 \\
\hline Medetera abstrusa & 20 & 28 & Old & All used & $\begin{array}{l}\text { Aspen (Oak, } \\
\text { Birch) }\end{array}$ & 0.25 \\
\hline Medetera borealis & 13 & 24 & Old & All used & Birch (Aspen) & 0.19 \\
\hline Medetera jugalis & 11 & 17 & $\begin{array}{l}\text { Young } \\
\text { (Old) }\end{array}$ & Thin (Medium) & Aspen & 0.09 \\
\hline Medetera setiventris & 14 & 53 & Young & $\begin{array}{l}\text { Coarse, Medium } \\
\text { (Thin) }\end{array}$ & Spruce & 0.10 \\
\hline Medetera tristis & 19 & 29 & Old & $\begin{array}{l}\text { Coarse, Medium } \\
\text { (Thn) }\end{array}$ & $\begin{array}{l}\text { Aspen, Birch, } \\
\text { Oak }\end{array}$ & 0.31 \\
\hline $\begin{array}{l}\text { Homalocephala } \\
\text { biumbrata }\end{array}$ & 10 & 126 & Young & $\begin{array}{l}\text { Coarse (Medium, } \\
\text { Thin) }\end{array}$ & Aspen & 0.08 \\
\hline Stegana coleoptrata ${ }^{\mathrm{b}}$ & 30 & 157 & All used & $\begin{array}{l}\text { Coarse, Medium } \\
\text { (Thin) }\end{array}$ & Birch & 0.21 \\
\hline Tanyptera atrata & 17 & 25 & Old & All used & Birch, Oak & 0.25 \\
\hline Tanyptera nigricornis & 20 & 37 & Old & All used & Birch & 0.13 \\
\hline
\end{tabular}

${ }^{\text {a }}$ Gaurax spp. includes males of G. fungivorous and G. dubius (both known to develop in bracket fungi) and females not determined to species

${ }^{\mathrm{b}}$ Stegana coleoptera also includes a few unidentified Stegana individuals 
Among the identified material, 15 taxa were found in $>10$ samples and thereby numerous enough for statistical comparisons (Table 1). Association with all categories of tree species, diameter classes and substrate age were found as well as several cases when there was no difference between categories (Table 1). For Coleoptera, 58 species were included and their association with the variables are given in "Appendix 1".

The median niche breadth for Diptera was 0.13 and for Coleoptera 0.20 (Table 2), with the respective averages not significantly different from each other with 0.20 and 0.23 respectively (Fig. 1a, b, Table 2). The average niche breadths for the single variables Age, Diameter and Tree species were also similar between the two groups (Table 2). However, Diptera had a larger proportion of specialists than Coleoptera (87\% vs 64\%; Fig. 1c, $\mathrm{Chi}^{2}=13.59$, df $=2, \mathrm{p}=0.001$ ).

There were some differences between the groups concerning the categories of wood with which they were mainly associated. However, Diptera and Coleoptera had similar distributions among the Age categories, both orders having more species using the old wood (Fig. 2a). For Diameter there was a difference, with more Diptera species than beetles associated with coarse wood (Fig. 2b). The relations with Diameter were however less strong than they were with the two other variables, and it was often the last variable to be selected into the models (Table 3). The percentage of species that used all diameter classes was also higher than the percentage using all Age classes and all Tree species (Fig. 2). Aspen tended to have a higher proportion of associated Diptera species than beetle species (Fig. 2c), with the opposite tendency prevailing for oak and spruce (Fig. 2c).

\section{Discussion}

Our results suggest that the saproxylic Diptera and Coleoptera in average are similar in their average level of specificity to certain types of dead wood but that dipterans have a higher share of specialists (Fig. 1). This seems surprising based on our present knowledge concerning substrate specificity among saproxylic dipterans (cited in the Introduction). However, this knowledge is rather sporadic, probably because of the non-specific collection methods generally used for dipterans. Details of their associations with certain woodsubstrates have therefore remained undetected (Rotheray 2016). The specificity is not surprising from an evolutionary perspective, as the circumstances during adaptation to use wood as a resource has been the same for both taxa. Since saproxylic dipterans are an even more species-rich group than the beetles, they would have needed to evolve at least similar degrees of specialisation in order to coexist in this habitat (HilleRisLambers et al. 2012).

It has been suggested that saproxylic dipterans have a weaker association with specific tree species than beetles, and instead are more associated with certain microhabitats (rot holes, sap-runs etc.) (Rotheray et al. 2001). Our study included only twigs and branches,

Table 2 Comparisons of niche breadths between Diptera and Coleoptera. p-values are probabilities for the significance of means being different according to t-tests

\begin{tabular}{llll}
\hline Variable & Diptera & Coleoptera & p-value \\
\hline No of species & 15 & 58 & \\
Niche breadth within age & 0.60 & 0.64 & 0.43 \\
Niche breadth within diameter & 0.78 & 0.72 & 0.39 \\
Niche breadth within tree species & 0.40 & 0.48 & 0.25 \\
Total niche breadth mean & 0.20 & 0.23 & 0.52 \\
Total niche breadth median & 0.13 & 0.20 & \\
\hline
\end{tabular}



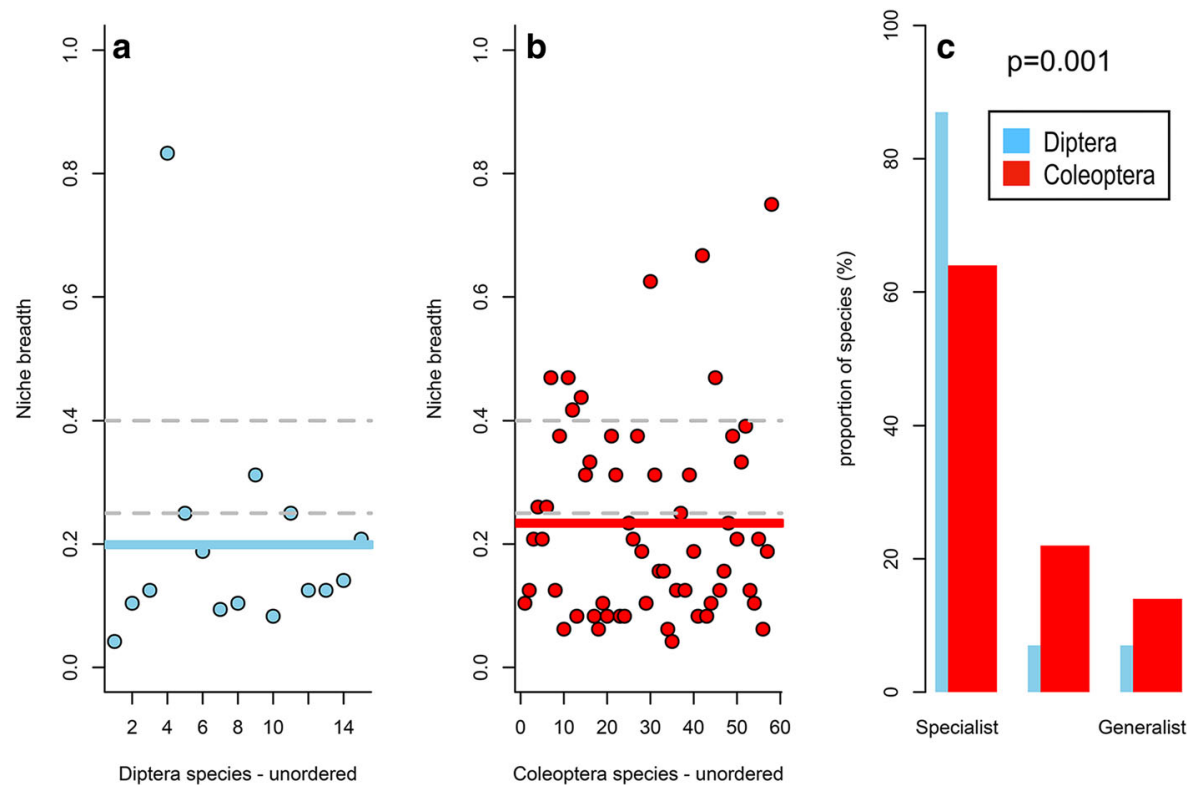

Fig. 1 The niche breadth distribution of a Diptera and $\mathbf{b}$ Coleoptera; average within taxa group indicated by the coloured straight line did not differ between the groups (t-test: $p=0.52$ ). Cut-off values for nichebreadth categories (specialist $\leq 0.25$; generalist $>0.4$ ) are shown with grey dotted lines. c Proportion of species in those three categories of specialisation, differed between Diptera and Coleoptera (Chi square $=13.4, p=0.001$, with colours for taxa as in $\mathbf{a}$ and $\mathbf{b}$ and width of bar proportional to the squareroots of the number of observations

and consequently we could not assess any affinity to microhabitats. However, in the comparison of associations with tree species, the groups were similarly specialised but with a tendency for the Diptera to be more specific than the Coleoptera. Both groups contained the full range of species affinities, from very specific to no association with tree species.

Although the difference was not significant, more dipterans than beetles seemed to be associated with aspen, and vice versa for oak and spruce. Aspen is often regarded as a keyelement for forest biodiversity (Esseen et al. 1997; Hammond et al. 2004), but data on species richness of saproxylic beetles do not usually show any extraordinary diversity (Gossner et al. 2016; Jonsell et al. 2007, 1998; Lindhe and Lindelöw 2004). However, our study suggests that if the Diptera were to be included, the richness of the insect assemblage hosted by aspen would be ranked higher. The tendency we found for oak confirm conclusions drawn in earlier studies (Rotheray et al. 2001). While it is the most species-rich tree species when it comes to saproxylic beetles (Jonsell et al. 1998), its richness of saproxylic Diptera seems lower than many other tree species (Rotheray et al. 2001).

Dipterans are assumed to use mainly moist and shaded environments (Rotheray et al 2001). Our finding of more Diptera species than beetle species in the coarse wood class might be because of this importance of moisture: thicker pieces of wood dry slower than thin pieces. On the other hand, the wood in this study had a maximum diameter of $15 \mathrm{~cm}$, which should not be very resistant to drying out. Moreover, the environment was open, sun-exposed clearcuts, which is a dry environment. This suggests even more strongly that some Diptera species are associated with dry and warm conditions. Similar results were shown for dipterans in stumps on clear-fellings (Jonsell et al. 2019). It is probable that the Diptera species associated 
a

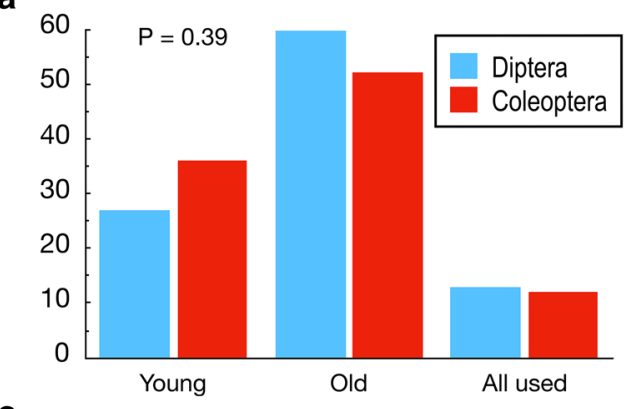

C

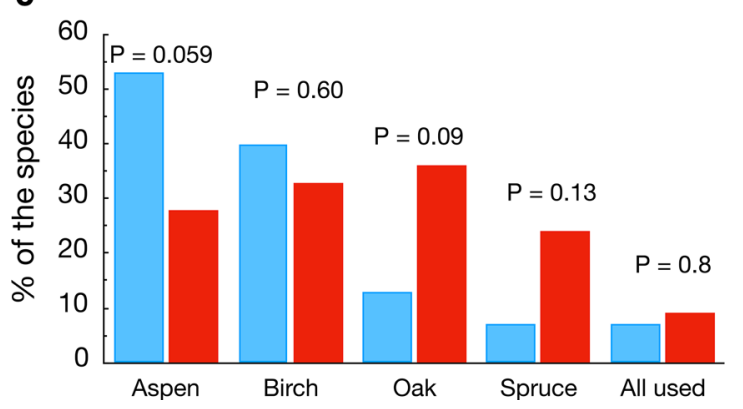

b

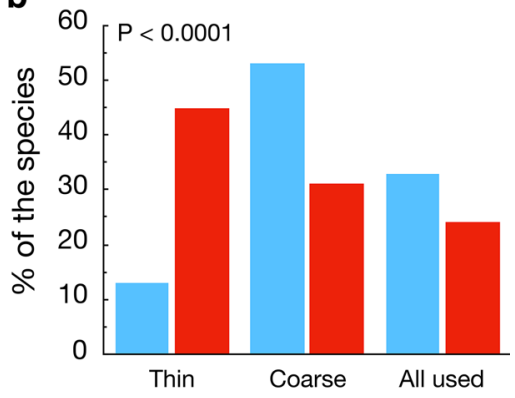

Fig. 2 Comparisons of substrate associations between Diptera and Coleoptera for the three variables a Age, b Diameter and c Tree species. p-values are for Pearson Chi square test of a contingency table. The null hypothesis for a Age and b Diameter was that all three categories have an equal share of species from the two groups. For $\mathbf{c}$ Tree species the null hypothesis was, for each tree species, that both groups have an equal share of users

Table 3 Summary of the number of species within each variable (in italics) that was selected as first, second, third or not included at all. The order of variable inclusion in the stepwise-selection indicates how relevant the different variables are for the species

\begin{tabular}{lllll}
\hline & First selected & Second selected & Third selected & Not included \\
\hline Diptera & & & & \\
Age & 5 & 5 & 4 & 1 \\
Diameter & 2 & 6 & 5 & 5 \\
Tree species & 8 & & & 1 \\
Coleoptera & & 27 & 8 & 5 \\
Age & 18 & 14 & 34 & 3 \\
Diameter & 6 & 15 & 5 & 5 \\
Tree species & 33 & & \\
\hline
\end{tabular}

with moist wood are confined to less sun- and wind-exposed sites than clear-cuts (Jonsell et al. 2019). There might also be a higher number of species in that wood compared to the wood on clear-cuts. Nevertheless, we can conclude that some dipterans might be threatened by harvesting bioenergy material from clear-cuts, in the same way as are many beetle species living in sun-exposed wood (Jonsell and Schroeder 2014).

A limitation of our study is that only part of the dipteran species community was analysed. Most of the Nematocera and part of the Brachycera were not included in the study. For 
Brachycera, data in the literature are too scarce to suggest anything general about their associations to dead wood types. The fungus gnats, Mycetophilidae on the other hand, have been specifically identified as a group that have problems coping with clear-cutting (Økland 1996; Økland et al. 2005). It is a family within Nematocera (midges), that is highly associated with fungi (Hackman and Meinander 1979; Jakovlev 2011), and might be more dependent on shade and moisture than other dipterans. Real comparisons of fauna between moist and dry, or between sun-exposed and shaded conditions are needed for firmer conclusions on this subject.

It should be highlighted that the individual models of each species are designed to identify the distribution of affinity to substrate qualities for comparison between the two taxonomic groups. Thus, the assumptions of each model have been kept constant to enable this comparison and are not customized to the distribution of each species. This is a valid assumption for the general comparison within the scope of this paper, however the coefficients for the individual species should not be used to make further occupancy predictions outside the range of this study (see e.g. Guisan and Zimmerman 2000 for discussion on model-building for generality vs. precision).

\section{Practical implications}

Our study underlines the high value of aspen wood. This tree species is already acknowledged as a key feature for biodiversity in Scandinavian boreal forests (Niemelä 1997) but our suggestion that a large diversity of saproxylic flies are dependent on aspen adds even more value to its role as a key species.

In general, our results suggest that dipterans actually are somewhat more specialised in their association with wood types than coleopterans are. Any policy that might be implemented based on the assumption that dipterans, being generalists, are less vulnerable, therefore risks underestimating the susceptibility of this group to forestry decisions. This fact and the similarities between the groups suggest that the measures already in place for mitigating saproxylic beetles may also work for saproxylic flies (Brachycera). More research, however, is needed in relation to dead wood under closed canopies in standing forest.

Acknowledgements Open access funding provided by Swedish University of Agricultural Sciences. Jesper Hansson and Lena Wedmo are thanked for the field and lab work carried out many years ago. We thank Baraa Alkhaled for sorting the samples. Alejandro Ruete and Olof Widenfalk gave valuable statistical advice. We are grateful to three anonymous reviewers who gave valuable comments on earlier versions of this manuscript. The Swedish Energy agency financed the field-work in previous projects, and Skogssällskapet (The Swedish Forest Society Foundation) financed the analysis of the dipterans under Project No. 1415-141 171-8.

Open Access This article is licensed under a Creative Commons Attribution 4.0 International License, which permits use, sharing, adaptation, distribution and reproduction in any medium or format, as long as you give appropriate credit to the original author(s) and the source, provide a link to the Creative Commons licence, and indicate if changes were made. The images or other third party material in this article are included in the article's Creative Commons licence, unless indicated otherwise in a credit line to the material. If material is not included in the article's Creative Commons licence and your intended use is not permitted by statutory regulation or exceeds the permitted use, you will need to obtain permission directly from the copyright holder. To view a copy of this licence, visit http://creativecommons.org/licenses/by/4.0/.

\section{Appendix 1}

See Table 4. 
Table 4 Categories (niches) with which different beetle species were associated according to the models

\begin{tabular}{|c|c|c|c|c|c|c|}
\hline \multirow[t]{2}{*}{ Species } & \multicolumn{2}{|c|}{ No of } & \multicolumn{3}{|c|}{ Substrate associations } & \multirow{2}{*}{$\begin{array}{l}\text { Niche } \\
\text { breadth }\end{array}$} \\
\hline & Obs & Inds & Age & Diameter & Tree species & \\
\hline $\begin{array}{l}\text { Phloeocharis } \\
\text { subtilissima }\end{array}$ & 60 & 120 & $\begin{array}{l}\text { Old } \\
\quad \text { (young) }\end{array}$ & $\begin{array}{l}\text { Thin, Med. } \\
\text { (Coarse) }\end{array}$ & $\begin{array}{l}\text { Asp., Oak (Birch, } \\
\text { Spr.) }\end{array}$ & 0.469 \\
\hline Phloeopora corticalis & 18 & 28 & All used & $\begin{array}{l}\text { Med. (Thin, } \\
\text { Coarse) }\end{array}$ & All used & 0.667 \\
\hline Dadobia immersa & 50 & 113 & $\begin{array}{l}\text { Old } \\
\quad \text { (young) }\end{array}$ & $\begin{array}{l}\text { Thin, Med. } \\
\text { (Coarse) }\end{array}$ & $\begin{array}{l}\text { Birch,Oak (Asp., } \\
\text { Spr.) }\end{array}$ & 0.469 \\
\hline Dinaraea aequata & 18 & 44 & $\begin{array}{l}\text { Old } \\
\text { (young) }\end{array}$ & $\begin{array}{l}\text { Coarse, Med. } \\
\text { (Thin) }\end{array}$ & Aspen, Birch, Oak & 0.469 \\
\hline Leptusa fumida & 46 & 104 & $\begin{array}{l}\text { Old } \\
\quad \text { (young) }\end{array}$ & Thin, Med & $\begin{array}{l}\text { Asp., Birch, Oak } \\
\text { (Spr.) }\end{array}$ & 0.437 \\
\hline Leptusa ruficollis & 24 & 52 & $\begin{array}{l}\text { Old } \\
\quad \text { (young) }\end{array}$ & $\begin{array}{l}\text { Thin, Med. } \\
\text { (Coarse) }\end{array}$ & All used & 0.625 \\
\hline $\begin{array}{l}\text { Anomognathus } \\
\text { cuspidat }\end{array}$ & 44 & 115 & All used & $\begin{array}{l}\text { Med. (Thin, } \\
\text { Coarse) }\end{array}$ & Aspen (Birch, Oak) & 0.333 \\
\hline $\begin{array}{l}\text { Lygistopterus } \\
\text { sanguineus }\end{array}$ & 14 & 29 & Old & $\begin{array}{l}\text { Med. (Thin, } \\
\text { Coarse) }\end{array}$ & All used & 0.333 \\
\hline $\begin{array}{l}\text { Anthaxia } \\
\quad \text { quadripunctata }\end{array}$ & 12 & 19 & All used & $\begin{array}{l}\text { Thin Coarse } \\
\text { (Med.) }\end{array}$ & Spruce & 0.208 \\
\hline Chrysobothris affinis & 23 & 97 & Young & $\begin{array}{l}\text { Thin, Med. } \\
\text { (Coarse) }\end{array}$ & Oak (Birch) & 0.156 \\
\hline Agrilus angustulus & 34 & 480 & Young & $\begin{array}{l}\text { Thin (Med., } \\
\text { Coarse) }\end{array}$ & Oak & 0.083 \\
\hline Agrilus sulcicollis & 23 & 111 & $\begin{array}{r}\text { Young } \\
\text { (old) }\end{array}$ & $\begin{array}{l}\text { Coarse, Med. } \\
\text { (Thin) }\end{array}$ & Oak & 0.156 \\
\hline Agrilus betuleti & 38 & 129 & Young & Thin (Med.) & Birch & 0.062 \\
\hline Agrilus suvorovi & 41 & 441 & Young & $\begin{array}{l}\text { Med. (Thin, } \\
\text { Coarse) }\end{array}$ & Aspen & 0.083 \\
\hline $\begin{array}{l}\text { Nemozoma } \\
\text { elongatum }\end{array}$ & 12 & 32 & All used & Med. (Thin) & Spruce (Oak) & 0.188 \\
\hline Dasytes niger & 45 & 72 & Old & $\begin{array}{l}\text { Thin, Med. } \\
\text { (Coarse) }\end{array}$ & $\begin{array}{l}\text { Birch, Spr. (Asp., } \\
\text { Oak) }\end{array}$ & 0.312 \\
\hline Dasytes caeruleus & 27 & 43 & $\begin{array}{l}\text { Old } \\
\quad \text { (young) }\end{array}$ & Thin, Med & $\begin{array}{l}\text { Asp., Oak (Birch, } \\
\text { Spr.) }\end{array}$ & 0.375 \\
\hline Dasytes plumbeus & 33 & 43 & $\begin{array}{l}\text { Old } \\
\quad \text { (young) }\end{array}$ & $\begin{array}{l}\text { Thin (Med., } \\
\text { Coarse) }\end{array}$ & $\begin{array}{l}\text { Oak, Spr. (Asp., } \\
\text { Birch) }\end{array}$ & 0.375 \\
\hline Rhizophagus dispar & 23 & 32 & $\begin{array}{l}\text { Old } \\
\quad \text { (young) }\end{array}$ & $\begin{array}{l}\text { Coarse, Med. } \\
\text { (Thin) }\end{array}$ & Birch (Aspen, Oak) & 0.312 \\
\hline Latridius minutus & 15 & 23 & $\begin{array}{r}\text { Young } \\
\text { (old) }\end{array}$ & $\begin{array}{l}\text { Thin, Med. } \\
\text { (Coarse) }\end{array}$ & Aspen (Birch) & 0.234 \\
\hline Dienerella vincenti & 14 & 53 & All used & Coarse (Med.) & $\begin{array}{l}\text { Asp., Birch (Oak, } \\
\text { Spr.) }\end{array}$ & 0.375 \\
\hline Cis micans & 131 & 1650 & Old & $\begin{array}{l}\text { Coarse (Thin, } \\
\text { Med.) }\end{array}$ & Aspen (Birch) & 0.125 \\
\hline Cis submicans & 22 & 311 & Old & Coarse & Aspen & 0.042 \\
\hline Cis boleti & 77 & 544 & Old & $\begin{array}{l}\text { Coarse, Med. } \\
\text { (Thin) }\end{array}$ & Aspen (Birch, Oak) & 0.208 \\
\hline
\end{tabular}


Table 4 continued

\begin{tabular}{|c|c|c|c|c|c|c|}
\hline \multirow[t]{2}{*}{ Species } & \multicolumn{2}{|c|}{ No of } & \multicolumn{3}{|c|}{ Substrate associations } & \multirow{2}{*}{$\begin{array}{l}\text { Niche } \\
\text { breadth }\end{array}$} \\
\hline & Obs & Inds & Age & Diameter & Tree species & \\
\hline Cis punctulatus & 18 & 68 & Old & $\begin{array}{l}\text { Coarse, Med. } \\
\text { (Thin) }\end{array}$ & Spruce & 0.104 \\
\hline Orthocis alni & 49 & 97 & Old & $\begin{array}{c}\text { Thin, Med. } \\
\text { (Coarse) }\end{array}$ & All used & 0.417 \\
\hline Cis festivus & 27 & 114 & Old & $\begin{array}{l}\text { Med. (Thin, } \\
\text { Coarse) }\end{array}$ & $\begin{array}{c}\text { Birch, Oak } \\
\text { (Spruce) }\end{array}$ & 0.208 \\
\hline Sulcacis nitidus & 123 & 1860 & Old & $\begin{array}{l}\text { Coarse (Thin, } \\
\text { Med.) }\end{array}$ & Aspen, Birch (Oak) & 0.208 \\
\hline $\begin{array}{l}\text { Octotemnus } \\
\text { glabriculus }\end{array}$ & 69 & 469 & Old & $\begin{array}{l}\text { Coarse, Med. } \\
\text { (Thin) }\end{array}$ & Aspen, Birch (Oak) & 0.260 \\
\hline Synchita humeralis & 28 & 110 & $\begin{array}{l}\text { Old } \\
\text { (young) }\end{array}$ & $\begin{array}{l}\text { Thin, Med. } \\
\text { (Coarse) }\end{array}$ & Birch (Aspen) & 0.234 \\
\hline Bitoma crenata & 55 & 141 & $\begin{array}{l}\text { Old } \\
\text { (young) }\end{array}$ & $\begin{array}{l}\text { Med. (Thin, } \\
\text { Coarse) }\end{array}$ & $\begin{array}{l}\text { Birch, Oak (Asp., } \\
\text { Spr.) }\end{array}$ & 0.375 \\
\hline $\begin{array}{l}\text { Schizotus } \\
\quad \text { pectinicornis }\end{array}$ & 81 & 219 & Old & $\begin{array}{l}\text { Coarse, Med. } \\
\text { (Thin) }\end{array}$ & Birch, Oak (Aspen) & 0.260 \\
\hline Corticeus linearis & 30 & 74 & Young & $\begin{array}{l}\text { Med. (Thin, } \\
\text { Coarse) }\end{array}$ & Spruce & 0.083 \\
\hline $\begin{array}{l}\text { Mordella } \\
\quad \text { holomelaena }\end{array}$ & 32 & 70 & Old & All used & Birch, Oak (Aspen) & 0.312 \\
\hline Orchesia undulata & 19 & 97 & Old & $\begin{array}{l}\text { Coarse (Thin, } \\
\text { Med.) }\end{array}$ & Oak & 0.083 \\
\hline $\begin{array}{l}\text { Leptura } \\
\qquad \text { quadrifasciata }\end{array}$ & 13 & 24 & Old & $\begin{array}{l}\text { Coarse (Thin, } \\
\text { Med.) }\end{array}$ & Birch (Aspen) & 0.125 \\
\hline Molorchus minor & 14 & 20 & All used & $\begin{array}{c}\text { Thin, Med. } \\
\text { (Coarse) }\end{array}$ & Spruce & 0.208 \\
\hline Rusticoclytus rusticus & 22 & 78 & Young & Coarse (Med.) & Aspen & 0.062 \\
\hline Clytus arietis & 12 & 24 & Old & $\begin{array}{l}\text { Thin Coarse } \\
\text { (Med.) }\end{array}$ & Oak & 0.104 \\
\hline Plagionotus arcuatus & 25 & 148 & Young & $\begin{array}{l}\text { Coarse, Med. } \\
\text { (Thin) }\end{array}$ & Oak & 0.104 \\
\hline $\begin{array}{l}\text { Pogonocherus } \\
\text { fasciculat }\end{array}$ & 30 & 119 & Young & $\begin{array}{l}\text { Med. (Thin, } \\
\text { Coarse) }\end{array}$ & Spruce & 0.083 \\
\hline $\begin{array}{l}\text { Aegomorphus } \\
\text { clavipes }\end{array}$ & 21 & 34 & Old & All used & Birch (Aspen, Oak) & 0.250 \\
\hline Leiopus nebulosus & 17 & 41 & $\begin{array}{r}\text { Young } \\
\text { (old) }\end{array}$ & $\begin{array}{l}\text { Coarse (Thin, } \\
\text { Med.) }\end{array}$ & Oak & 0.125 \\
\hline Saperda scalaris & 20 & 32 & All used & $\begin{array}{l}\text { Coarse, Med. } \\
\text { (Thin) }\end{array}$ & Oak (Birch) & 0.312 \\
\hline Allandrus undulatus & 21 & 35 & Young & Thin (Med.) & $\begin{array}{l}\text { Aspen (Birch, } \\
\text { Spruce) }\end{array}$ & 0.125 \\
\hline Platystomos albinus & 19 & 36 & $\begin{array}{l}\text { Old } \\
\text { (young) }\end{array}$ & Thin, Med & Birch (Oak) & 0.188 \\
\hline Anthonomus rubi & 12 & 14 & $\begin{array}{l}\text { Old } \\
\text { (young) }\end{array}$ & All used & All used & 0.750 \\
\hline Magdalis violacea & 20 & 55 & $\begin{array}{r}\text { Young } \\
\text { (old) }\end{array}$ & $\begin{array}{c}\text { Thin (Med., } \\
\text { Coarse) }\end{array}$ & Spruce & 0.125 \\
\hline
\end{tabular}


Table 4 continued

\begin{tabular}{|c|c|c|c|c|c|c|}
\hline \multirow[t]{2}{*}{ Species } & \multicolumn{2}{|c|}{ No of } & \multicolumn{3}{|c|}{ Substrate associations } & \multirow{2}{*}{$\begin{array}{l}\text { Niche } \\
\text { breadth }\end{array}$} \\
\hline & Obs & Inds & Age & Diameter & Tree species & \\
\hline Magdalis carbonaria & 48 & 206 & Young & $\begin{array}{l}\text { Thin (Med., } \\
\text { Coarse) }\end{array}$ & Birch & 0.083 \\
\hline Trachodes hispidus & 13 & 45 & $\begin{array}{l}\text { Old } \\
\text { (young) }\end{array}$ & $\begin{array}{c}\text { Thin, Med. } \\
\text { (Coarse) }\end{array}$ & $\begin{array}{c}\text { Birch, Oak } \\
\text { (Spruce) }\end{array}$ & 0.391 \\
\hline Scolytus intricatus & 34 & 1314 & Young & $\begin{array}{c}\text { Thin, Med. } \\
\text { (Coarse) }\end{array}$ & Oak & 0.104 \\
\hline Pityogenes chalcogra & 276 & 34,177 & Young & $\begin{array}{c}\text { Thin, Med. } \\
\text { (Coarse) }\end{array}$ & Spruce & 0.104 \\
\hline $\begin{array}{l}\text { Pityogenes } \\
\text { bidentatus }\end{array}$ & 18 & 142 & Young & Thin, Med & Spruce & 0.083 \\
\hline $\begin{array}{l}\text { Dryocoetes } \\
\text { autographus }\end{array}$ & 25 & 115 & $\begin{array}{r}\text { Young } \\
\text { (old) }\end{array}$ & Coarse (Med.) & $\begin{array}{l}\text { Spruce (Aspen, } \\
\text { Oak) }\end{array}$ & 0.188 \\
\hline $\begin{array}{l}\text { Crypturgus } \\
\text { subcribrosus }\end{array}$ & 55 & 512 & Old & $\begin{array}{l}\text { Med. (Thin, } \\
\text { Coarse) }\end{array}$ & Spruce (Birch) & 0.125 \\
\hline Anisandrus dispar & 17 & 619 & $\begin{array}{r}\text { Young } \\
\text { (old) }\end{array}$ & $\begin{array}{l}\text { Thin, Med. } \\
\text { (Coarse) }\end{array}$ & Oak & 0.156 \\
\hline $\begin{array}{l}\text { Trypophloeus } \\
\text { binodulus }\end{array}$ & 12 & 807 & Young & Thin (Med.) & Aspen & 0.062 \\
\hline $\begin{array}{l}\text { Pityophthorus } \\
\text { microgra }\end{array}$ & 51 & 1683 & Young & Med. (Thin) & Spruce & 0.062 \\
\hline
\end{tabular}

Within parenthesis are secondary categories of substrate, categories which the species use-but less frequently. The models used were more sensitive and included more explanatory variables than previously published models (Jonsell 2008). Species names and systematic order follow Löbl and Smetana (20032012)

\section{Appendix 2}

Results from species-wise multiple regression where the response variable, abundance of a species, was explained by the three categorical wood type variables. Associations with the categories of wood types were assessed in the Full models presented below. The strength of the associations was then used for defining niches and secondary niches, which subsequently was used to calculate niche breadth (details in material and methods). For all models df null/resid $=739 / 733$. The proportion of explained variation in abundance of each species is calculated as $(1-$ (Residual deviance/Null deviance $)) \times 100$.

For variables explaining too small amount of variation according to AIC-informed forward-step selection $(\mathrm{k}>2)$ of the three variables, all categories were defined as belonging to the niche (see Material and methods for more details). The order of selection is given below each full model.

For Diptera, families are listed in systematic order and species within them alphabetically, for Coleopterans systematic order follow Löbl and Smetana (2003-2012). 


\section{DIPTERA}

Drapetis abrollensis

Explained variation: $39 \%$

\begin{tabular}{llc}
\hline Category & Estimate & $\operatorname{Pr}(>|\mathrm{z}|)$ \\
\hline Intercept & -3.173 & 0.000 \\
Birch & 2.287 & 0.000 \\
Oak & 1.121 & 0.093 \\
Spruce & -1.506 & 0.192 \\
Thin & -17.798 & 0.985 \\
Medium & 0.696 & 0.016 \\
Young & -4.174 & 0.000 \\
\hline
\end{tabular}

Selection order Age, tree species, diameter.

Gaurax spp.

(include males of G. fungivorous and G. dubius and females not determined to species). Explained variation: $34 \%$

\begin{tabular}{llc}
\hline Category & Estimate & $\operatorname{Pr}(>|\mathrm{z}|)$ \\
\hline Intercept & -0.683 & 0.010 \\
Birch & -0.989 & 0.015 \\
Oak & -18.663 & 0.991 \\
Spruce & -2.459 & 0.001 \\
Thin & -18.538 & 0.988 \\
Medium & -1.266 & 0.004 \\
Young & -1.910 & 0.000 \\
\hline
\end{tabular}

Selection order Diameter, tree species, age

Lonchaea fugax

Explained variation: $56 \%$

\begin{tabular}{llc}
\hline Category & Estimate & $\operatorname{Pr}(>|\mathrm{z}|)$ \\
\hline Intercept & -3.235 & 0.001 \\
Birch & -5.962 & 0.000 \\
Oak & -18.425 & 0.961 \\
Spruce & -5.935 & 0.000 \\
Thin & -6.233 & 0.000 \\
Medium & -2.963 & 0.000 \\
\hline
\end{tabular}




\begin{tabular}{lll}
\hline Category & Estimate & $\operatorname{Pr}(>|\mathrm{z}|)$ \\
\hline Young & 5.771 & 0.000 \\
\hline
\end{tabular}

Selection order Tree species, diameter, age

\section{Lonchaea fraxina}

Explained variation: $57 \%$

\begin{tabular}{llc}
\hline Category & Estimate & $\operatorname{Pr}(>|\mathrm{z}|)$ \\
\hline Intercept & -1.010 & 0.002 \\
Birch & -20.143 & 0.988 \\
Oak & -20.276 & 0.991 \\
Spruce & -20.280 & 0.989 \\
Thin & 0.875 & 0.027 \\
Medium & 1.438 & 0.000 \\
Young & -3.526 & 0.000 \\
\hline
\end{tabular}

Selection order Tree species, age, diameter

\section{Lonchaea patens}

Explained variation: $53 \%$

\begin{tabular}{llc}
\hline Category & Estimate & $\operatorname{Pr}(>|\mathrm{z}|)$ \\
\hline Intercept & -0.469 & 0.064 \\
Birch & -3.400 & 0.000 \\
Oak & -3.668 & 0.000 \\
Spruce & -20.715 & 0.993 \\
Thin & -0.301 & 0.431 \\
Medium & -0.037 & 0.918 \\
Young & -19.699 & 0.989 \\
\hline
\end{tabular}

Selection order Tree species, age

Lonchaea sylvatica

Explained variation: $3 \%$

\begin{tabular}{llc}
\hline Category & Estimate & $\operatorname{Pr}(>|z|)$ \\
\hline Intercept & -3.135 & 0.000 \\
Birch & -0.088 & 0.884 \\
Oak & 0.266 & 0.674 \\
\hline
\end{tabular}




\begin{tabular}{llc}
\hline Category & Estimate & $\operatorname{Pr}(>|\mathrm{z}|)$ \\
\hline Spruce & 0.190 & 0.746 \\
Thin & -1.286 & 0.028 \\
Medium & -0.573 & 0.218 \\
Young & 0.233 & 0.581 \\
\hline
\end{tabular}

Selection order Diameter

\section{Medetera abstrusa}

Explained variation: $25 \%$

\begin{tabular}{lll}
\hline Category & Estimate & $\operatorname{Pr}(>|\mathrm{z}|)$ \\
\hline Intercept & -2.215 & 0.000 \\
Birch & -1.279 & 0.009 \\
Oak & -0.839 & 0.086 \\
Spruce & -2.352 & 0.002 \\
Thin & 0.771 & 0.148 \\
Medium & 0.712 & 0.187 \\
Young & -3.545 & 0.001 \\
\hline
\end{tabular}

Selection order Age, tree species

Medetera borealis

Explained variation: $37 \%$

\begin{tabular}{llc}
\hline Category & Estimate & $\operatorname{Pr}(>|\mathrm{z}|)$ \\
\hline Intercept & -2.999 & 0.000 \\
Birch & 0.901 & 0.073 \\
Oak & -18.708 & 0.995 \\
Spruce & -18.699 & 0.994 \\
Thin & 0.311 & 0.585 \\
Medium & 0.638 & 0.237 \\
Young & -19.472 & 0.992 \\
\hline
\end{tabular}

Selection order Age, tree species

Medetera jugalis

Explained variation: $53 \%$

\begin{tabular}{lcc}
\hline Category & Estimate & $\operatorname{Pr}(>|z|)$ \\
\hline Intercept & -22.957 & 0.995 \\
Birch & -20.696 & 0.996 \\
\hline
\end{tabular}




\begin{tabular}{llc}
\hline Category & Estimate & $\operatorname{Pr}(>|z|)$ \\
\hline Oak & -20.456 & 0.997 \\
Spruce & -20.480 & 0.996 \\
Thin & 19.583 & 0.996 \\
Medium & 18.094 & 0.996 \\
Young & 2.263 & 0.028 \\
\hline
\end{tabular}

Selection order Tree species, diameter, age

Medetera setiventris

Explained variation: $53 \%$

\begin{tabular}{llc}
\hline Category & Estimate & $\operatorname{Pr}(>|\mathrm{z}|)$ \\
\hline Intercept & -40.258 & 0.989 \\
Birch & 0.117 & 1.000 \\
Oak & 0.247 & 1.000 \\
Spruce & 20.688 & 0.994 \\
Thin & -2.231 & 0.000 \\
Medium & -0.034 & 0.905 \\
Young & 19.373 & 0.988 \\
\hline
\end{tabular}

Selection order Tree species, age, diameter

Medetera tristis

Explained variation: $29 \%$

\begin{tabular}{llc}
\hline Category & Estimate & $\operatorname{Pr}(>|\mathrm{z}|)$ \\
\hline Intercept & -1.739 & 0.000 \\
Birch & -0.011 & 0.980 \\
Oak & -0.198 & 0.695 \\
Spruce & -17.176 & 0.985 \\
Thin & -1.610 & 0.012 \\
Medium & -0.121 & 0.758 \\
Young & -3.457 & 0.001 \\
\hline
\end{tabular}

Selection order Age, tree species, diameter. 
Homalocephala biumbrata

Explained variation: $50 \%$

\begin{tabular}{llc}
\hline Category & Estimate & $\operatorname{Pr}(>|\mathrm{z}|)$ \\
\hline Intercept & -17.505 & 0.980 \\
Birch & -21.200 & 0.991 \\
Oak & -21.168 & 0.993 \\
Spruce & -21.157 & 0.992 \\
Thin & -2.066 & 0.000 \\
Medium & -2.126 & 0.000 \\
Young & 18.826 & 0.979 \\
\hline
\end{tabular}

Selection order Tree species, age, diameter

Stegana coleoptrata

include a few unidentified Stegana individuals.

Explained variation: $33 \%$

\begin{tabular}{llc}
\hline Category & Estimate & $\operatorname{Pr}(>|z|)$ \\
\hline Intercept & -4.061 & 0.000 \\
Birch & 4.083 & 0.000 \\
Oak & -0.421 & 0.731 \\
Spruce & -14.701 & 0.981 \\
Thin & -1.874 & 0.000 \\
Medium & -0.607 & 0.000 \\
Young & 0.399 & 0.016 \\
\hline
\end{tabular}

Selection order Tree species, diameter, age

Tanyptera atrata

Explained variation: $39 \%$

\begin{tabular}{llc}
\hline Category & Estimate & $\operatorname{Pr}(>|\mathrm{z}|)$ \\
\hline Intercept & -21.103 & 0.994 \\
Birch & 19.017 & 0.994 \\
Oak & 19.207 & 0.994 \\
Spruce & -0.301 & 1.000 \\
Thin & -0.527 & 0.368 \\
Medium & 0.446 & 0.341 \\
Young & -19.302 & 0.992 \\
\hline
\end{tabular}

Selection order Age, tree species 
Tanyptera nigricornis

Explained variation: $43 \%$

\begin{tabular}{lll}
\hline Category & Estimate & $\operatorname{Pr}(>|\mathrm{z}|)$ \\
\hline Intercept & -21.279 & 0.994 \\
Birch & 19.839 & 0.994 \\
Oak & 17.430 & 0.995 \\
Spruce & 16.332 & 0.995 \\
Thin & 0.609 & 0.152 \\
Medium & 0.118 & 0.800 \\
Young & -19.616 & 0.991 \\
\hline
\end{tabular}

Selection order Tree species, age

\section{COLEOPTERA}

Phloeocharis subtilissima

Explained variation: $12 \%$

\begin{tabular}{llc}
\hline Category & Estimate & $\operatorname{Pr}(>|\mathrm{z}|)$ \\
\hline Intercept & -2.018 & 0.000 \\
Birch & -0.346 & 0.157 \\
Oak & 0.393 & 0.093 \\
Spruce & -1.370 & 0.000 \\
Thin & 1.127 & 0.000 \\
Medium & 0.983 & 0.001 \\
Young & -1.033 & 0.000 \\
\hline
\end{tabular}

Selection order Tree species, age, diameter

Phloeopora corticalis

Explained variation: $5 \%$

\begin{tabular}{llc}
\hline Category & Estimate & $\operatorname{Pr}(>|\mathrm{z}|)$ \\
\hline Intercept & -3.853 & 0.000 \\
Birch & 0.126 & 0.794 \\
Oak & 0.132 & 0.813 \\
Spruce & -0.714 & 0.256 \\
Thin & 0.271 & 0.666 \\
Medium & 1.182 & 0.034 \\
\hline
\end{tabular}




\begin{tabular}{llr}
\hline Category & Estimate & $\operatorname{Pr}(>|\mathrm{z}|)$ \\
\hline Young & -0.005 & 0.989 \\
\hline
\end{tabular}

Selection order Diameter

Dadobia immersa

Explained variation: $15 \%$

\begin{tabular}{llc}
\hline Category & Estimate & $\operatorname{Pr}(>|\mathrm{z}|)$ \\
\hline Intercept & -3.348 & 0.000 \\
Birch & 0.898 & 0.004 \\
Oak & 0.964 & 0.004 \\
Spruce & 0.149 & 0.673 \\
Thin & 1.697 & 0.000 \\
Medium & 1.654 & 0.000 \\
Young & -1.538 & 0.000 \\
\hline
\end{tabular}

Selection order Age, diameter, tree species

Dinaraea aequata

Explained variation: $17 \%$

\begin{tabular}{llc}
\hline Category & Estimate & $\operatorname{Pr}(>|z|)$ \\
\hline Intercept & -2.152 & 0.000 \\
Birch & 0.028 & 0.939 \\
Oak & 0.201 & 0.617 \\
Spruce & -2.794 & 0.007 \\
Thin & -1.303 & 0.024 \\
Medium & 0.669 & 0.053 \\
Young & -1.366 & 0.000 \\
\hline
\end{tabular}

Selection order Diameter, tree species, age

Leptusa fumida

Explained variation: $18 \%$

\begin{tabular}{llc}
\hline Category & Estimate & $\operatorname{Pr}(>|z|)$ \\
\hline Intercept & -3.972 & 0.000 \\
Birch & -0.074 & 0.764 \\
Oak & 0.193 & 0.466 \\
\hline
\end{tabular}




\begin{tabular}{llc}
\hline Category & Estimate & $\operatorname{Pr}(>|\mathrm{z}|)$ \\
\hline Spruce & -1.694 & 0.000 \\
Thin & 3.032 & 0.000 \\
Medium & 3.056 & 0.000 \\
Young & -1.250 & 0.000 \\
\hline
\end{tabular}

Selection order Diameter, age, tree species

\section{Leptusa ruficollis}

Explained variation: 5\%

\begin{tabular}{llc}
\hline Category & Estimate & $\operatorname{Pr}(>|\mathrm{z}|)$ \\
\hline Intercept & -3.395 & 0.000 \\
Birch & -0.067 & 0.867 \\
Oak & 0.069 & 0.875 \\
Spruce & 0.111 & 0.778 \\
Thin & 1.305 & 0.008 \\
Medium & 1.361 & 0.006 \\
Young & -0.932 & 0.002 \\
\hline
\end{tabular}

Selection order Age, diameter

\section{Anomognathus cuspidatus}

Explained variation: $25 \%$

\begin{tabular}{lll}
\hline Category & Estimate & $\operatorname{Pr}(>|\mathrm{z}|)$ \\
\hline Intercept & -1.326 & 0.000 \\
Birch & -1.953 & 0.000 \\
Oak & -1.785 & 0.000 \\
Spruce & -4.623 & 0.000 \\
Thin & 0.351 & 0.258 \\
Medium & 1.225 & 0.000 \\
Young & -0.114 & 0.545 \\
\hline
\end{tabular}

Selection order Tree species, diameter

Lygistopterus sanguineus

Explained variation: $23 \%$

\begin{tabular}{llc}
\hline Category & Estimate & $\operatorname{Pr}(>|\mathrm{z}|)$ \\
\hline Intercept & -4.168 & 0.000 \\
Birch & 1.078 & 0.090 \\
\hline
\end{tabular}




\begin{tabular}{llc}
\hline Category & Estimate & $\operatorname{Pr}(>|z|)$ \\
\hline Oak & 0.489 & 0.503 \\
Spruce & 0.395 & 0.567 \\
Thin & 0.804 & 0.235 \\
Medium & 1.620 & 0.009 \\
Young & -18.681 & 0.988 \\
\hline
\end{tabular}

Selection order Age, diameter

Anthaxia quadripunctata

Explained variation: $35 \%$

\begin{tabular}{lll}
\hline Category & Estimate & $\operatorname{Pr}(>|\mathrm{z}|)$ \\
\hline Intercept & -21.860 & 0.994 \\
Birch & 0.038 & 1.000 \\
Oak & -0.004 & 1.000 \\
Spruce & 19.903 & 0.995 \\
Thin & -0.319 & 0.511 \\
Medium & -1.718 & 0.028 \\
Young & 0.185 & 0.687 \\
\hline
\end{tabular}

Selection order Tree species, diameter.

Chrysobothris affinis

Explained variation: $46 \%$

\begin{tabular}{lll}
\hline Category & Estimate & $\operatorname{Pr}(>|\mathrm{z}|)$ \\
\hline Intercept & -39.585 & 0.979 \\
Birch & 18.283 & 0.989 \\
Oak & 20.282 & 0.988 \\
Spruce & 0.331 & 1.000 \\
Thin & 1.153 & 0.000 \\
Medium & 0.464 & 0.159 \\
Young & 18.815 & 0.979 \\
\hline
\end{tabular}

Selection order Tree species, age, diameter 
Agrilus angustulus

Explained variation: $68 \%$

\begin{tabular}{lll}
\hline Category & Estimate & $\operatorname{Pr}(>|\mathrm{z}|)$ \\
\hline Intercept & -22.934 & 0.965 \\
Birch & 13.316 & 0.980 \\
Oak & 20.221 & 0.969 \\
Spruce & 0.322 & 1.000 \\
Thin & 0.862 & 0.000 \\
Medium & -0.867 & 0.000 \\
Young & 4.491 & 0.000 \\
\hline
\end{tabular}

Selection order Tree species, age, diameter

Agrilus sulcicollis

Explained variation: $54 \%$

\begin{tabular}{llc}
\hline Category & Estimate & $\operatorname{Pr}(>|\mathrm{z}|)$ \\
\hline Intercept & -21.612 & 0.984 \\
Birch & 14.717 & 0.989 \\
Oak & 20.088 & 0.985 \\
Spruce & 0.173 & 1.000 \\
Thin & -0.898 & 0.001 \\
Medium & 0.155 & 0.462 \\
Young & 2.138 & 0.000 \\
\hline
\end{tabular}

Selection order Tree species, age, diameter

Agrilus betuleti

Explained variation: $64 \%$

\begin{tabular}{lll}
\hline Category & Estimate & $\operatorname{Pr}(>|\mathrm{z}|)$ \\
\hline Intercept & -26.981 & 0.985 \\
Birch & 20.145 & 0.989 \\
Oak & 0.353 & 1.000 \\
Spruce & 0.332 & 1.000 \\
Thin & 3.035 & 0.000 \\
Medium & 1.053 & 0.096 \\
Young & 4.590 & 0.000 \\
\hline
\end{tabular}

Selection order Tree species, age, diameter 
Agrilus suvorovi

Explained variation: $64 \%$

\begin{tabular}{llc}
\hline Category & Estimate & $\operatorname{Pr}(>|\mathrm{z}|)$ \\
\hline Intercept & -4.962 & 0.000 \\
Birch & -20.588 & 0.978 \\
Oak & -20.350 & 0.984 \\
Spruce & -20.394 & 0.980 \\
Thin & 0.038 & 0.833 \\
Medium & 1.407 & 0.000 \\
Young & 5.652 & 0.000 \\
\hline
\end{tabular}

Selection order Tree species, age, diameter

Nemozoma elongatum

Explained variation: $32 \%$

\begin{tabular}{llc}
\hline Category & Estimate & $\operatorname{Pr}(>|\mathrm{z}|)$ \\
\hline Intercept & -23.787 & 0.989 \\
Birch & -0.010 & 1.000 \\
Oak & 17.059 & 0.992 \\
Spruce & 19.314 & 0.991 \\
Thin & 2.106 & 0.045 \\
Medium & 2.841 & 0.006 \\
Young & 0.614 & 0.093 \\
\hline
\end{tabular}

Selection order Tree species, diameter, age

Dasytes niger

Explained variation: $28 \%$

\begin{tabular}{lll}
\hline Category & Estimate & $\operatorname{Pr}(>|\mathrm{z}|)$ \\
\hline Intercept & -2.806 & 0.000 \\
Birch & 0.431 & 0.252 \\
Oak & -0.366 & 0.458 \\
Spruce & 0.708 & 0.052 \\
Thin & 1.183 & 0.002 \\
Medium & 0.958 & 0.012 \\
Young & -4.369 & 0.000 \\
\hline
\end{tabular}

Selection order Age, diameter, tree species 
Dasytes caeruleus

Explained variation: $11 \%$

\begin{tabular}{lll}
\hline Category & Estimate & $\operatorname{Pr}(>|\mathrm{z}|)$ \\
\hline Intercept & -4.607 & 0.000 \\
Birch & -0.881 & 0.037 \\
Oak & -0.027 & 0.945 \\
Spruce & -0.992 & 0.031 \\
Thin & 3.079 & 0.003 \\
Medium & 2.518 & 0.015 \\
Young & -0.709 & 0.026 \\
\hline
\end{tabular}

Selection order Diameter, age, tree species

Dasytes plumbeus

Explained variation: $22 \%$

\begin{tabular}{llc}
\hline Category & Estimate & $\operatorname{Pr}(>|\mathrm{z}|)$ \\
\hline Intercept & -3.755 & 0.000 \\
Birch & -0.593 & 0.377 \\
Oak & 1.164 & 0.026 \\
Spruce & 1.118 & 0.026 \\
Thin & 1.479 & 0.001 \\
Medium & -0.368 & 0.544 \\
Young & -1.195 & 0.001 \\
\hline
\end{tabular}

Selection order Diameter, tree species, age

Rhizophagus dispar

Explained variation: $19 \%$

\begin{tabular}{lll}
\hline Category & Estimate & $\operatorname{Pr}(>|\mathrm{z}|)$ \\
\hline Intercept & -2.845 & 0.000 \\
Birch & 0.866 & 0.062 \\
Oak & -0.307 & 0.634 \\
Spruce & -2.119 & 0.050 \\
Thin & -0.510 & 0.346 \\
Medium & 0.604 & 0.156 \\
Young & -1.644 & 0.000 \\
\hline
\end{tabular}

Selection order Tree species, age, diameter 


\section{Latridius minutus}

Explained variation: $16 \%$

\begin{tabular}{llc}
\hline Category & Estimate & $\operatorname{Pr}(>|\mathrm{z}|)$ \\
\hline Intercept & -4.005 & 0.000 \\
Birch & -1.206 & 0.013 \\
Oak & -2.320 & 0.025 \\
Spruce & -2.758 & 0.008 \\
Thin & 1.331 & 0.084 \\
Medium & 1.273 & 0.101 \\
Young & 0.699 & 0.143 \\
\hline
\end{tabular}

Selection order Tree species, diameter, age

Dienerella vincenti

Explained variation: $15 \%$

\begin{tabular}{lcc}
\hline Category & Estimate & $\operatorname{Pr}(>|z|)$ \\
\hline Intercept & -1.147 & 0.000 \\
Birch & -0.074 & 0.811 \\
Oak & -2.053 & 0.006 \\
Spruce & -0.946 & 0.019 \\
Thin & -3.875 & 0.000 \\
Medium & -1.082 & 0.000 \\
Young & -0.313 & 0.260 \\
\hline
\end{tabular}

Selection order Diameter, tree species

Cis micans

Explained variation: $54 \%$

\begin{tabular}{llc}
\hline Category & Estimate & $\operatorname{Pr}(>|\mathrm{z}|)$ \\
\hline Intercept & 3.254 & 0.000 \\
Birch & -0.854 & 0.000 \\
Oak & -3.333 & 0.000 \\
Spruce & -3.856 & 0.000 \\
Thin & -2.069 & 0.000 \\
Medium & -0.760 & 0.000 \\
Young & -4.553 & 0.000 \\
\hline
\end{tabular}

Selection order Age, tree species, diameter. 


\section{Cis submicans}

Explained variation: $48 \%$

\begin{tabular}{lll}
\hline Category & Estimate & $\operatorname{Pr}(>|\mathrm{z}|)$ \\
\hline Intercept & 2.334 & 0.000 \\
Birch & -2.828 & 0.000 \\
Oak & -4.829 & 0.000 \\
Spruce & -3.944 & 0.000 \\
Thin & -3.075 & 0.000 \\
Medium & -2.468 & 0.000 \\
Young & -5.796 & 0.000 \\
\hline
\end{tabular}

Selection order Tree species, age, diameter

\section{Cis boleti}

Explained variation: $42 \%$

\begin{tabular}{llc}
\hline Category & Estimate & $\operatorname{Pr}(>|\mathrm{z}|)$ \\
\hline Intercept & 1.679 & 0.000 \\
Birch & -1.089 & 0.000 \\
Oak & -1.405 & 0.000 \\
Spruce & -3.715 & 0.000 \\
Thin & -1.848 & 0.000 \\
Medium & 0.243 & 0.007 \\
Young & -18.895 & 0.949 \\
\hline
\end{tabular}

Selection order Age, tree species, diameter.

Cis punctulatus

Explained variation: $47 \%$

\begin{tabular}{lll}
\hline Category & Estimate & $\operatorname{Pr}(>|\mathrm{z}|)$ \\
\hline Intercept & -18.751 & 0.984 \\
Birch & 14.233 & 0.988 \\
Oak & -0.292 & 1.000 \\
Spruce & 18.455 & 0.984 \\
Thin & -1.553 & 0.001 \\
Medium & 0.293 & 0.266 \\
Young & -4.114 & 0.000 \\
\hline
\end{tabular}

Selection order Tree species, age, diameter 
Orthocis alni

Explained variation: $25 \%$

\begin{tabular}{llc}
\hline Category & Estimate & $\operatorname{Pr}(>|\mathrm{z}|)$ \\
\hline Intercept & -2.603 & 0.000 \\
Birch & -0.495 & 0.077 \\
Oak & -0.429 & 0.169 \\
Spruce & -0.321 & 0.236 \\
Thin & 1.794 & 0.000 \\
Medium & 1.960 & 0.000 \\
Young & -3.315 & 0.000 \\
\hline
\end{tabular}

Selection order Age, diameter

Cis festivus (earlier Orthocis festivus).

Explained variation: $34 \%$

\begin{tabular}{lll}
\hline Category & Estimate & $\operatorname{Pr}(>|\mathrm{z}|)$ \\
\hline Intercept & -19.596 & 0.978 \\
Birch & 17.79 & 0.980 \\
Oak & 17.931 & 0.980 \\
Spruce & 15.630 & 0.982 \\
Thin & 0.441 & 0.259 \\
Medium & 1.955 & 0.000 \\
Young & -3.165 & 0.000 \\
\hline
\end{tabular}

Selection order Age, tree species, diameter.

Sulcacis nitidus (earlier Sulcacis affinis).

Explained variation: $44 \%$

\begin{tabular}{lll}
\hline Category & Estimate & $\operatorname{Pr}(>|\mathrm{z}|)$ \\
\hline Intercept & 2.976 & 0.000 \\
Birch & -0.116 & 0.018 \\
Oak & -1.541 & 0.000 \\
Spruce & -4.051 & 0.000 \\
Thin & -1.516 & 0.000 \\
Medium & -0.974 & 0.000 \\
Young & -5.337 & 0.000 \\
\hline
\end{tabular}

Selection order Age, tree species, diameter. 
Octotemnus glabriculus

Explained variation: $38 \%$

\begin{tabular}{lll}
\hline Category & Estimate & $\operatorname{Pr}(>|\mathrm{z}|)$ \\
\hline Intercept & 1.153 & 0.000 \\
Birch & -0.666 & 0.000 \\
Oak & -1.846 & 0.000 \\
Spruce & -3.797 & 0.000 \\
Thin & -0.609 & 0.000 \\
Medium & 0.485 & 0.000 \\
Young & -5.010 & 0.000 \\
\hline
\end{tabular}

Selection order Age, tree species, diameter.

Synchita humeralis

Explained variation: $29 \%$

\begin{tabular}{llc}
\hline Category & Estimate & $\operatorname{Pr}(>|\mathrm{z}|)$ \\
\hline Intercept & -3.167 & 0.000 \\
Birch & 1.291 & 0.000 \\
Oak & -17.742 & 0.987 \\
Spruce & -17.762 & 0.984 \\
Thin & 1.607 & 0.000 \\
Medium & 1.872 & 0.000 \\
Young & -1.453 & 0.000 \\
\hline
\end{tabular}

Selection order Tree species, age, diameter

\section{Bitoma crenata}

Explained variation: $23 \%$

\begin{tabular}{lll}
\hline Category & Estimate & $\operatorname{Pr}(>|\mathrm{z}|)$ \\
\hline Intercept & -2.130 & 0.000 \\
Birch & 0.978 & 0.000 \\
Oak & 0.362 & 0.221 \\
Spruce & -0.802 & 0.024 \\
Thin & 0.233 & 0.416 \\
Medium & 1.313 & 0.000 \\
Young & -2.024 & 0.000 \\
\hline
\end{tabular}

Selection order Age, tree species, diameter. 
Schizotus pectinicornis

Explained variation: $48 \%$

\begin{tabular}{lll}
\hline Category & Estimate & $\operatorname{Pr}(>|\mathrm{z}|)$ \\
\hline Intercept & -0.745 & 0.000 \\
Birch & 0.853 & 0.000 \\
Oak & 0.378 & 0.081 \\
Spruce & -3.300 & 0.000 \\
Thin & -0.661 & 0.002 \\
Medium & 0.540 & 0.001 \\
Young & -19.433 & 0.975 \\
\hline
\end{tabular}

Selection order Age, tree species, diameter.

Corticeus linearis

Explained variation: $49 \%$

\begin{tabular}{llc}
\hline Category & Estimate & $\operatorname{Pr}(>|\mathrm{z}|)$ \\
\hline Intercept & -8.395 & 0.000 \\
Birch & 0.449 & 0.714 \\
Oak & -14.515 & 0.990 \\
Spruce & 4.331 & 0.000 \\
Thin & 0.323 & 0.418 \\
Medium & 1.340 & 0.000 \\
Young & 2.948 & 0.000 \\
\hline
\end{tabular}

Selection order Tree species, age, diameter

\section{Mordella holomelaena}

Explained variation: $34 \%$

\begin{tabular}{llc}
\hline Category & Estimate & $\operatorname{Pr}(>|\mathrm{z}|)$ \\
\hline Intercept & -2.962 & 0.000 \\
Birch & 1.725 & 0.000 \\
Oak & 1.434 & 0.004 \\
Spruce & -2.017 & 0.066 \\
Thin & 0.578 & 0.065 \\
Medium & 0.263 & 0.429 \\
Young & -18.281 & 0.977 \\
\hline
\end{tabular}

Selection order Age, tree species 


\section{Orchesia undulata}

Explained variation: $46 \%$

\begin{tabular}{lll}
\hline Category & Estimate & $\operatorname{Pr}(>|\mathrm{z}|)$ \\
\hline Intercept & -1.902 & 0.000 \\
Birch & 0.014 & 0.980 \\
Oak & 2.890 & 0.000 \\
Spruce & -1.210 & 0.148 \\
Thin & -1.267 & 0.000 \\
Medium & -2.125 & 0.000 \\
Young & -18.388 & 0.977 \\
\hline
\end{tabular}

Selection order Tree species, age, diameter

\section{Leptura quadrifasciata}

Explained variation: $41 \%$

\begin{tabular}{llc}
\hline Category & Estimate & $\operatorname{Pr}(>|\mathrm{z}|)$ \\
\hline Intercept & -2.036 & 0.000 \\
Birch & 0.987 & 0.050 \\
Oak & -18.589 & 0.995 \\
Spruce & -18.556 & 0.994 \\
Thin & -1.414 & 0.013 \\
Medium & -1.001 & 0.040 \\
Young & -19.258 & 0.991 \\
\hline
\end{tabular}

Selection order Age, tree species, diameter.

Molorchus minor

Explained variation: $38 \%$

\begin{tabular}{llc}
\hline Category & Estimate & $\operatorname{Pr}(>|\mathrm{z}|)$ \\
\hline Intercept & -24.341 & 0.994 \\
Birch & -0.005 & 1.000 \\
Oak & 0.104 & 1.000 \\
Spruce & 20.008 & 0.995 \\
Thin & 2.198 & 0.035 \\
Medium & 1.868 & 0.078 \\
Young & 0.500 & 0.273 \\
\hline
\end{tabular}

Selection order Tree species, diameter 
Rusticoclytus rusticus

Explained variation: $63 \%$

\begin{tabular}{lll}
\hline Category & Estimate & $\operatorname{Pr}(>|\mathrm{z}|)$ \\
\hline Intercept & -2.245 & 0.000 \\
Birch & -3.816 & 0.000 \\
Oak & -19.847 & 0.990 \\
Spruce & -19.834 & 0.988 \\
Thin & -4.639 & 0.000 \\
Medium & -1.950 & 0.000 \\
Young & 3.142 & 0.000 \\
\hline
\end{tabular}

Selection order Tree species, diameter, age.

Clytus arietis

Explained variation: $52 \%$

\begin{tabular}{llc}
\hline Category & Estimate & $\operatorname{Pr}(>|\mathrm{z}|)$ \\
\hline Intercept & -21.134 & 0.994 \\
Birch & 17.137 & 0.995 \\
Oak & 19.951 & 0.994 \\
Spruce & -0.270 & 1.000 \\
Thin & 0.516 & 0.265 \\
Medium & -0.987 & 0.153 \\
Young & -18.808 & 0.990 \\
\hline
\end{tabular}

Selection order Tree species, diameter, age.

\section{Plagionotus arcuatus}

Explained variation: $66 \%$

\begin{tabular}{lll}
\hline Category & Estimate & $\operatorname{Pr}(>|\mathrm{z}|)$ \\
\hline Intercept & -40.367 & 0.988 \\
Birch & 0.118 & 1.000 \\
Oak & 22.179 & 0.993 \\
Spruce & 0.220 & 1.000 \\
Thin & -1.742 & 0.000 \\
Medium & -0.160 & 0.355 \\
Young & 19.478 & 0.981 \\
\hline
\end{tabular}

Selection order Tree species, diameter, age. 


\section{Pogonocherus hispidulus}

Explained variation: $53 \%$

\begin{tabular}{lll}
\hline Category & Estimate & $\operatorname{Pr}(>|\mathrm{z}|)$ \\
\hline Intercept & -24.459 & 0.978 \\
Birch & 14.317 & 0.987 \\
Oak & 0.335 & 1.000 \\
Spruce & 19.423 & 0.982 \\
Thin & 0.844 & 0.012 \\
Medium & 1.608 & 0.000 \\
Young & 4.166 & 0.000 \\
\hline
\end{tabular}

Selection order Tree species, diameter, age.

\section{Aegomorphus clavipes}

Explained variation: $36 \%$

\begin{tabular}{llc}
\hline Category & Estimate & $\operatorname{Pr}(>|\mathrm{z}|)$ \\
\hline Intercept & -2.819 & 0.000 \\
Birch & 1.544 & 0.004 \\
Oak & -0.660 & 0.446 \\
Spruce & -16.422 & 0.986 \\
Thin & -0.506 & 0.277 \\
Medium & 0.131 & 0.742 \\
Young & -3.665 & 0.000 \\
\hline
\end{tabular}

Selection order Age, tree species

\section{Leiopus nebulosus}

Explained variation: $41 \%$

\begin{tabular}{lll}
\hline Category & Estimate & $\operatorname{Pr}(>|\mathrm{z}|)$ \\
\hline Intercept & -21.832 & 0.990 \\
Birch & 17.350 & 0.992 \\
Oak & 19.900 & 0.991 \\
Spruce & 0.138 & 1.000 \\
Thin & -1.031 & 0.007 \\
Medium & -1.212 & 0.003 \\
Young & 1.855 & 0.000 \\
\hline
\end{tabular}

Selection order Tree species, diameter, age. 
Saperda scalaris

Explained variation: $29 \%$

\begin{tabular}{lll}
\hline Category & Estimate & $\operatorname{Pr}(>|\mathrm{z}|)$ \\
\hline Intercept & -20.406 & 0.991 \\
Birch & 18.245 & 0.992 \\
Oak & 19.131 & 0.992 \\
Spruce & -0.089 & 1.000 \\
Thin & -2.182 & 0.004 \\
Medium & -0.074 & 0.839 \\
Young & -0.625 & 0.094 \\
\hline
\end{tabular}

Selection order Tree species, diameter, age.

\section{Allandrus undulatus}

Explained variation: $31 \%$

\begin{tabular}{llc}
\hline Category & Estimate & $\operatorname{Pr}(>|\mathrm{z}|)$ \\
\hline Intercept & -6.965 & 0.000 \\
Birch & -0.744 & 0.042 \\
Oak & -2.432 & 0.018 \\
Spruce & -2.179 & 0.003 \\
Thin & 2.845 & 0.005 \\
Medium & 1.342 & 0.214 \\
Young & 3.182 & 0.002 \\
\hline
\end{tabular}

Selection order Age, diameter, tree species.

\section{Platystomos albinus}

Explained variation: $29 \%$

\begin{tabular}{lll}
\hline Category & Estimate & $\operatorname{Pr}(>|\mathrm{z}|)$ \\
\hline Intercept & -6.842 & 0.000 \\
Birch & 3.062 & 0.003 \\
Oak & 0.808 & 0.510 \\
Spruce & -0.309 & 0.827 \\
Thin & 2.771 & 0.007 \\
Medium & 2.373 & 0.022 \\
Young & -1.334 & 0.001 \\
\hline
\end{tabular}

Selection order Tree species, age, diameter 


\section{Anthonomus rubi}

Explained variation: $12 \%$

\begin{tabular}{lll}
\hline Category & Estimate & $\operatorname{Pr}(>|\mathrm{z}|)$ \\
\hline Intercept & -21.832 & 0.990 \\
Birch & 17.350 & 0.992 \\
Oak & 19.900 & 0.991 \\
Spruce & 0.138 & 1.000 \\
Thin & -1.031 & 0.007 \\
Medium & -1.212 & 0.003 \\
Young & 1.855 & 0.000 \\
\hline
\end{tabular}

Selection order Age

Magdalis violacea

Explained variation: $37 \%$

\begin{tabular}{llc}
\hline Category & Estimate & $\operatorname{Pr}(>|\mathrm{z}|)$ \\
\hline Intercept & -21.859 & 0.983 \\
Birch & 16.236 & 0.987 \\
Oak & 0.202 & 1.000 \\
Spruce & 18.814 & 0.985 \\
Thin & 0.817 & 0.015 \\
Medium & -0.514 & 0.244 \\
Young & 1.987 & 0.000 \\
\hline
\end{tabular}

Selection order Tree species, age, diameter

\section{Magdalis carbonaria}

Explained variation: $56 \%$

\begin{tabular}{llc}
\hline Category & Estimate & $\operatorname{Pr}(>|\mathrm{z}|)$ \\
\hline Intercept & -23.938 & 0.979 \\
Birch & 19.743 & 0.983 \\
Oak & 0.313 & 1.000 \\
Spruce & 15.463 & 0.987 \\
Thin & 2.107 & 0.000 \\
Medium & 1.107 & 0.001 \\
Young & 3.103 & 0.000 \\
\hline
\end{tabular}

Selection order Tree species, age, diameter 
Trachodes hispidus

Explained variation: $19 \%$

\begin{tabular}{lll}
\hline Category & Estimate & $\operatorname{Pr}(>|\mathrm{z}|)$ \\
\hline Intercept & -5.179 & 0.000 \\
Birch & 2.527 & 0.014 \\
Oak & 3.099 & 0.002 \\
Spruce & 1.020 & 0.362 \\
Thin & 0.949 & 0.043 \\
Medium & 1.020 & 0.029 \\
Young & -2.128 & 0.000 \\
\hline
\end{tabular}

Selection order Age, tree species, diameter.

Scolytus intricatus

Explained variation: $61 \%$

\begin{tabular}{lll}
\hline Category & Estimate & $\operatorname{Pr}(>|\mathrm{z}|)$ \\
\hline Intercept & -10.655 & 0.000 \\
Birch & -0.226 & 0.873 \\
Oak & 7.713 & 0.000 \\
Spruce & 0.092 & 0.948 \\
Thin & 0.778 & 0.000 \\
Medium & 0.462 & 0.000 \\
Young & 5.508 & 0.000 \\
\hline
\end{tabular}

Selection order Tree species, age, diameter

Pityogenes chalcographus

Explained variation: $72 \%$

\begin{tabular}{lll}
\hline Category & Estimate & $\operatorname{Pr}(>|\mathrm{z}|)$ \\
\hline Intercept & -6.507 & 0.000 \\
Birch & 0.426 & 0.009 \\
Oak & 0.311 & 0.122 \\
Spruce & 6.501 & 0.000 \\
Thin & 1.754 & 0.000 \\
Medium & 2.194 & 0.000 \\
Young & 4.150 & 0.000 \\
\hline
\end{tabular}

Selection order Tree species, age, diameter 


\section{Pityogenes bidentatus}

Explained variation: $45 \%$

\begin{tabular}{lll}
\hline Category & Estimate & $\operatorname{Pr}(>|\mathrm{z}|)$ \\
\hline Intercept & -24.946 & 0.977 \\
Birch & 0.079 & 1.000 \\
Oak & 15.053 & 0.986 \\
Spruce & 19.553 & 0.982 \\
Thin & 2.897 & 0.000 \\
Medium & 2.331 & 0.000 \\
Young & 3.404 & 0.000 \\
\hline
\end{tabular}

Selection order Tree species, age, diameter

Dryocoetes autographus

Explained variation: $31 \%$

\begin{tabular}{llc}
\hline Category & Estimate & $\operatorname{Pr}(>|\mathrm{z}|)$ \\
\hline Intercept & -2.570 & 0.000 \\
Birch & -0.972 & 0.049 \\
Oak & -0.348 & 0.459 \\
Spruce & 1.798 & 0.000 \\
Thin & -2.971 & 0.000 \\
Medium & -1.924 & 0.000 \\
Young & 1.498 & 0.000 \\
\hline
\end{tabular}

Selection order Diameter, tree species, age

Crypturgus subcribrosus

Explained variation: $41 \%$

\begin{tabular}{lll}
\hline Category & Estimate & $\operatorname{Pr}(>|\mathrm{z}|)$ \\
\hline Intercept & -17.235 & 0.962 \\
Birch & 17.225 & 0.962 \\
Oak & 12.789 & 0.972 \\
Spruce & 18.299 & 0.959 \\
Thin & -0.946 & 0.000 \\
Medium & 0.783 & 0.000 \\
Young & -3.553 & 0.000 \\
\hline
\end{tabular}

Selection order Tree species, age, diameter 
Anisandrus dispar

Explained variation: $37 \%$

\begin{tabular}{lll}
\hline Category & Estimate & $\operatorname{Pr}(>|\mathrm{z}|)$ \\
\hline Intercept & -6.765 & 0.000 \\
Birch & 2.387 & 0.000 \\
Oak & 5.205 & 0.000 \\
Spruce & -0.848 & 0.311 \\
Thin & 1.665 & 0.000 \\
Medium & 1.798 & 0.000 \\
Young & 2.163 & 0.000 \\
\hline
\end{tabular}

Selection order Tree species, age, diameter

Trypophloeus binodulus

Explained variation: $48 \%$

\begin{tabular}{llc}
\hline Category & Estimate & $\operatorname{Pr}(>|\mathrm{z}|)$ \\
\hline Intercept & -21.092 & 0.921 \\
Birch & -21.823 & 0.983 \\
Oak & -21.485 & 0.987 \\
Spruce & -21.532 & 0.984 \\
Thin & 5.874 & 0.000 \\
Medium & 4.902 & 0.000 \\
Young & 17.914 & 0.933 \\
\hline
\end{tabular}

Selection order Tree species, age, diameter

Pityophthorus micrographus

Explained variation: $53 \%$

\begin{tabular}{lll}
\hline Category & Estimate & $\operatorname{Pr}(>|\mathrm{z}|)$ \\
\hline Intercept & -22.446 & 0.907 \\
Birch & 12.368 & 0.949 \\
Oak & 12.090 & 0.950 \\
Spruce & 19.047 & 0.921 \\
Thin & 1.322 & 0.000 \\
Medium & 2.722 & 0.000 \\
Young & 4.298 & 0.000 \\
\hline
\end{tabular}

Selection order Tree species, age, diameter 


\section{References}

Burnham KP, Anderson DR (2002) Model selection and multimodel inference: a practical informationtheoretic approach. Springer, New York

Chesson P (2000) Mechanisms of maintenance of species diversity. Annu Rev Ecol Syst 31:343

Clavel J, Julliard R, Devictor V (2011) Worldwide decline of specialist species: toward a global functional homogenization? Front Ecol Environ 9:222-228

Ehnström B, Axelsson R (2002) Insektsgnag i bark och ved. ArtDatabanken. SLU, Uppsala

Esseen P-A, Ehnström B, Ericsson L, Sjöberg K (1997) Boreal forests. Ecol Bull 46:16-47

Gelman A, Hill J (2007) Data analysis using regression and multilevel/hierarchical models. Cambridge University Press, Cambridge

Gossner MM, Wende B, Levick S, Schall P, Floren A, Linsenmair KE, Steffan-Dewenter I, Schultze E-D, Weisser WW (2016) Deadwood enrichment in European forests: which tree species should be used to promote saproxylic beetle diversity? Biol Conserv 201:92-102

Guisan A, Zimmermann N (2000) Predictive habitat distribution models in ecology. Ecol Model 135:147-186

Hackman W, Meinander M (1979) Diptera feeding as larvae on macrofungi in Finland. Ann Zool Fenn 16:50-83

Halme P, Vartija N, Salmela J, Penttinen J, Norros V (2013) High within- and between-trunk variation in the nematoceran (Diptera) community and its physical environment in decaying aspen trunks. Insect Conserv Divers 6:502-512

Hammond HEJ, Langor DW, Spence JR (2004) Saproxylic beetles (Coleoptera) using Populus in boreal sapen stands of western Canada: spatiotemporal variation and conservation of assemblages. Can J For 34:1-19

HilleRisLambers J, Adler PB, Harpole WS, Levine JM, Mayfield MM (2012) Rethinking community assembly through the lens of coexistence theory. Annu Rev Ecol Evol Syst 43:227-248

Hutchinson GE (1959) Homage to Santa Rosalia, or why are there so many kinds of animals. Am Nat 93:145-159

Irmler U, Heller K, Warning J (1996) Age and tree species as factors influencing the population of insects living in dead wood (Coleoptera, Diptera: Sciaridae, Mycetophilidae). Pedobiologia 40:134-148

IUCN (2001) IUCN red list categories and criteria: version 3.1. IUCN Species Survival Commission, Gland and Cambridge

Jakovlev EB (1994) Palearctic Diptera associated with fungi and myxomycetes. Karelian Research Center Russian Academy of Science, Forest Reasearch Institute, Petrozavodsk

Jakovlev J (2011) Fungus gnats (Diptera: Sciaroidea) associated with dead wood and wood growing fungi: new rearing data from Finland and Russian Karelia and general analysis of known larval microhabitats in Europe. Entomol Fenn 22:157-189

Jonsell M (2008) Saproxylic beetle species in logging residues: which are they and which residues do they use? Norwegian Journal of Entomology 55:109-122

Jonsell M, Ols C, Hellqvist S (2019) Diptera in clear felling stumps like it dry. Scand J For Res Publ Online

Jonsell M, Hansson J (2007) Comparison of methods for sampling saproxylic beetles in fine wood. Entomol Fenn 18:232-241

Jonsell M, Hansson J, Wedmo L (2007) Diversity of saproxylic beetle species in logging residues in Sweden: comparisons between tree species and diameters. Biol Cons 138:89-99

Jonsell M, Schroeder LM (2014) Proportions of saproxylic beetle populations that utilise clear-cut stumps in a boreal landscape: biodiversity implications for stump harvest. For Ecol Manage 334:313-320

Jonsell M, Weslien J, Ehnström B (1998) Substrate requirements of red-listed saproxylic invertebrates in Sweden. Biodivers Conserv 7:749-764

Köhler F (2000) Totholzkäfer in Naturwaldzellen des nördlichen Rheinlands. Landesanstalt für Ökologie Bodenordnung und Forsten, Recklinghausen

Kouki J, Löfman S, Martikainen P, Rouvinen S, Uotila A (2001) Forest fragmentation in Fennoscandia: linking habitat requirements of wood-associated threatened species to landscape and habitat changes. Scand J For Res Suppl 7(3):27-37

Lindhe A, Lindelöw $\AA$ (2004) Cut high stumps of spruce, birch, aspen and oak as breeding substrates for saproxylic beetles. For Ecol Manage 203:1-20

Löbl I, Smetana A (2003-2012). Catalogue of palaearctic coleoptera, vol 1-8. Apollo Books, Stenstrup.

Lundborg A (1998) A sustainable forest fuel system in Sweden. Biomass Bioenerg 15:399-406

Niemelä J (1997) Invertebrates and boreal forest management. Conserv Biol 11:601-610

Økland B (1996) Unlogged forests: important sites for preserving the diversity of mycetophilids (Diptera: Sciariodea). Biol Conserv 76:297-310 
Økland B, Götmark F, Nordén B, Franc N, Kurina O, Polevoi A (2005) Regional diversity of mycetophilids (Diptera: Sciaroidea) in Scandinavian oak-dominated forests. Biol Conserv 121:9-20

Olsson U (2002) Generalized linear models. An applied approach. Studentlitteratur, Lund

Palm T (1959) Die Holz- und rindenkäfer der süd- und mittelschwedischen laubbäume. Opuscula Entomol Suppl 16:1-374

R Core Team (2018) R: a language and environment for statistical computing. R Foundation for Statistical Computing, Vienna. https://www.R-project.org/.

Rotheray GE (2016) Improving knowledge of the cyclorrhaphan larva (Diptera). J Nat Hist 50:2169-2198 Rotheray GE, Hancock G, Hewitt S, Horsefield D, MacGowan I, Robertson D, Watt K (2001) The biodiversity and conservation of saproxylic Diptera in Scotland. J Insect Conserv 5:77-85

Saalas U (1917) Die Fichtenkäfer Finnlands I. Ann Acad Sci Fenn Ser A 8:1-547

Siitonen J, Stokland JN (2012) Tree size. In: Stokland JN, Siitonen J, Jonsson BG (eds) Biodiversity in dead wood. Cambridge University Press, Cambridge, pp 183-193

Stokland JN, Siitonen J, Jonsson BG (2012) Biodiversity in dead wood. Cambridge University Press, Cambridge

Venables WN, Ripley BD (2002) Modern applied statistics with S, 4th edn. Springer, New York

Publisher's Note Springer Nature remains neutral with regard to jurisdictional claims in published maps and institutional affiliations.

\section{Affiliations}

\section{Mats Jonsell ${ }^{1}$ (D) $\cdot$ Lina A. Widenfalk ${ }^{1,2} \cdot$ Sven Hellqvist $^{3}$ (D)}

$\triangle$ Mats Jonsell

mats.jonsell@slu.se

1 Department of Ecology, Swedish University of Agricultural Sciences, Box 7044, 75007 Uppsala, Sweden

2 Present Address: Greensway AB, Ulls väg 24, 75651 Uppsala, Sweden

3 Älvtået 4, 90360 Umeå, Sweden 